\section{Indian health care Keeping it simple}

\section{Lucknow}

If India's ambitious target of "health for all" by the year 2000 is to be approached, then the present curative hospital-based, urban-centred health service may have to give way to simpler low-cost alternatives, especially in rural areas.

Some advances have been made in developing "appropriate technology" for health care. Low-cost audiovisual aids and teaching methods for various levels of health worker have been developed under the aegis of the Indian Council of Medical Research. The Central Scientific Instruments Organization has developed a cycle-ambulance with a stretcher for the patient and a seat for the attendant; a clinical thermometer with temperature ranges indicated as coloured bands for easy use by illiterate health volunteers; a simple apparatus for vasectomy, now ready for human trial; a fetal stethoscope which can detect a fetal heart beat at week 12 of pregnancy; a miniature cardioscope and a colorimeter. The Vector Control Centre, Pondicherry, has demonstrated that certain fishes such as Aplocheilus blochii and Gambusia affinis, can be used as effective controls of mosquitoes, on whose larvae they feed.

For maternal and child health care by traditional birth attendants, called dai, a simple dai kit has been developed at the Postgraduate Institute of Medical Education and Research, Chandigarh. The kit should reduce the risks of tetanus, by achieving better asepsis, and helps the birth attendants to spot mothers and infants at risk - again using colour-coding principles on measuring sticks and weighing scales.

A much-needed boost to rural health care should come with the recent decision of the Indian government to set up a national committee on appropriate technology for health care. The Indian Council of Medical Research is to provide technical support for the national health programme - and at a national workshop held recently by the council the value of community health volunteers and multipurpose health workers was underlined. Zaka Imam

\section{Blood products}

\section{Surplus sale}

Products extracted from donations to the British National Blood Transfusion Service, and for which the National Health Service has no use, may in future be sold to pharmaceutical companies, the government has decided. Although some companies have occasionally bought products from the transfusion service in small quantities, usually for research purposes, there have been no formal arrangements for buying in bulk. Thus British companies have had to buy from abroad.

The decision to sell off surplus blood products has emerged from a lengthy wrangle over the use of products that are now discarded, expected to be exacerbated as the transfusion service puts into operation a plan to make more blood plasma available for fractionation. There has also been a long discussion about the revamping and expansion of the Blood Products Laboratory, which carries out all fractionation of donated blood. The laboratory suffers from some of the problems of the former Lister Institute of Preventive Medicine, whose site it shares. The institute was closed in 1978 after it began to lose money and could not afford to modernize its facilities.

An earlier government suggestion that the Blood Products Laboratory be handed over to commercial management fell flat after many organizations, including blood donor groups, trades unions and Labour Members of Parliament, objected to the rise of blood donated by volunteers for overtly commercial purposes. As a compromise, the government has decided to keep the laboratory firmly under the wing of the Department of Health and to sell products surplus to the National Health Service's requirements. Any profits will be ploughed back into the health service, although it is not yet clear whether they will be spent on updating the laboratory.

The success of the scheme will depend on whether the laboratory can supply companies with products they need. Companies are negotiating with the health department, which has said only that outdated red cells and plasma fractions containing nonspecific antibodies will be available. Products for which the health service's demand exceeds supply, however, will not be for sale. They include factor 8 , the blood clotting agent used for treating haemophiliacs, and albumin.

Future sales will, however, depend on the plan to make more blood plasma available for fractionation, by substituting concentrates of red cells for whole blood in transfusions and on the laboratory's ability to take on the extra work. The aim is that by the end of 1982, the laboratory will have enough plasma to produce two-fifths, compared with one-fifth at present, of the national demand for factor 8 , in which it is hoped that Britain will ultimately be selfsufficient. That will mean that other products, such as factor 9, immunoglobulin and albumin, will be produced in excess and will be available for sale.

One company now discussing its needs with the Department of Health is Beechams Pharmaceuticals Limited, which would like to buy plasminogen for clinical trials in the treatment of deep-vein thrombosis. Whether the laboratory will be able and willing to supply such specific products, or will simply make certain plasma fractions available, remains to be seen.

\section{Paying court}

Forensic scientists in Britain are rather touchy at the moment, following the suspension of one of their number for allegedly failing to reveal crucial ambiguities in evidence on blood samples, and now the "demotion" of another for writing a research paper which is said to reveal detachment.

This second scientist resigned rather than accept a teaching post which he regarded as demotion - and then went to an industrial tribunal to claim what he saw to be effectively unfair dismissal. However, the tribunal rejected the scientist's claim, and he is to appeal to the Employment Appeal Tribunal in London on 3 September.

His paper, which appeared in the official journal of the British Academy of Forensic Science - Medicine, Science and the Law - in 1977 (vol. 17 no. 1, p.37), deals with the quantitative toxicology of corpses - addressing the issue of how to estimate a drug or poison dose. The paper uses a simple law of linear diffusion to relate the drug content of various organs (taken from the data sheets of real cases) to dose and time of death as estimated by the police and witnesses. The data are clearly very scattered and the fit loose, and the author concludes "A pessimistic view is that it is impossible to remove the last vestiges of alchemy from [forensic] toxicology because of the nature of the material for analysis. It may be, apart from the fact of death, that one cannot be absolutely certain of anything and there are always contrary authorities to be found".

This conclusion may not have recommended itself to the Forensic Science Service, which as part of the Home Office runs forensic science in the United Kingdom. Other forensic scientists may equally have been unsettled.

Robert Walgate

\section{US uranium \\ Falling demand}

\section{Washington}

A report from the US Department of Energy (DoE) has revealed just how depressed the domestic market for uranium has become. This was already evident from the dramatic price reduction in 1980 , when uranium oxide fell from $\$ 43$ to less than $\$ 30$ a pound. Now DoE has shown that, for the first time, the amount of new orders for future supplies placed by US utilities was more than outweighted by cancellations of existing commitments.

The DoE's report, A Survey of United States Uranium Marketing Activity, published last week, is based on information gathered from 60 utilities with nuclear reactor projects, 30 present or potential uranium users and five reactor manufacturers. It says that domestic 
buyers contracted with US primary producers for an extra 12,500 tons of $\mathrm{U}_{3} \mathrm{O}_{8}$ in 1980 , but that this was offset by a reduction of 25,600 tons for commitments made under previous contracts.

The survey showed that, despite the current depressed prices, most utilities and producers expect the price of uranium to rise sharply over the next decade; future contracts which guarantee a floor price for any 1 year quote an average of $\$ 75$ a pound by 1990 .

The drop in uranium demand is blamed on the extended licensing period faced by companies building new reactors, a reflection of increasingly stringent safety requirements and on the substantial reductior in estimates for future demand for electricity as the United States becomes more conservation-conscious, and energy costs continue to rise.

Some business analysts feel that the price of uranium may have bottomed out, at least temporarily. According to calculations by the Californian consulting company Nuclear Exchange Corporation (Nuexco), uranium prices remained virtually constant at $\$ 24$ a pound between April and June, and actually increased slightly last month.

However, the slump in prices - and demand - is clearly reflected in difficulties being faced by the uranium mining industry. Some estimate that as many as 4,000 workers, 25 per cent of the workforce, have been laid off.

This decline, too, is reflected in DoE statistics. In another report, soon to be published, the department notes that the uranium mining industry is entering a period of major retrenchment. Having initially planned to spend $\$ 316.5$ million on new mining facilities in 1981, for example, the industry now estimates that total spending will be only about $\$ 172$ million. Projections for capital spending on mill facilities have dropped even more dramatically, from $\$ 241.9$ million to $\$ 99.3$ million.

According to DoE officials, several processes are keeping the price of uranium oxide down. One is that many utilities, faced with high interest rates, are selling stockpiled uranium back to producers. Another is that, even though uranium mining has been cut back, production figures are still going up as companies work through stockpiles of ore. Nuexco had predicted a drop of 2.5 million pounds between 1979 and 1980 to about 34.5 million pounds - still about double the amount consumed by the nuclear industry.

In fact, however, production increased by 13 per cent to 42.5 million pounds. Some wastes which have already passed through the mill are being rerun, a way of obtaining more uranium oxide without having to pay for any extra mining. Some industry analysts feel that this will continue, so that even if demand picks up it will not be reflected by an immediate boost for the mining industry.

David Dickson
German cancer research Politics ousts science

\section{Brussels}

The scandal at the German Cancer Research Institute has grown into a national issue. The scientific director has resigned, the administrative director appears to have been removed, the oppositions parties (CDU/CSU) have attacked the government and the institute itself is now involved in internecine strife.

The national research centre in Heidelberg is a union of eight institutions centrally administered by the Bundes Ministerium für Forschung und Technologie (BMFT), with a 1981 budget of DM 79 million ( $\$ 1,817$ million). The latest scandal began with the appointment of Dr Hans Neurath, born in Vienna, but previously professor of biochemistry at the University of Washington, as the centre's scientific director. The post had been vacant since 1976 and the chief administrator, Bodo Spiekermann, was relieved to have found someone with the qualifications and drive to attempt the much needed reorganization.

The other directors of the centre were not consulted about the appointment and soon raised a storm about the professor's demand that the institute pay for a villa in addition to his salary of DM 167,000 a year. The attack soon broadened to Neurath's qualifications and it turned out that he had in fact previously only been scientific advisor to the University of Seattle.

The centre's director for toxicology and chemotherapy, Professor Dietrich Schmaehl, declared that Neurath could not possibly be sufficiently knowledgeable about cancer research to take over leadership of the centre. Nothing daunted, Neurath set about appointing outside investigators to assess the value of the research projects in hand with the intention of directing resources to the most promising areas. The multidisciplinary, clinically-orientated approach was rejected, and Neurath, with the support of the ministry's director, Wolfgang Spinke, proposed to cut back on activities such as nuclear medicine and chemotherapy.

The zeal with which Neurath set about reforming the institute inflamed the already poisoned atmosphere, the battle amongst the divided researchers spilled over into the press and by May this year it had become a political issue, with the opposition, CDU/CSU, siding with Neurath's opponents and the government defending its appointee who by then had been in charge for a year.

The opposition claimed that the administration of the centre was chaotic and scandalous. By July CDU/CSU was describing the working climate as completely destroyed by internal power struggies complete with the "terrorization of administrative personnel".

On 24 July, Neurath announced that he had resigned but would explain the reasons for his decision only in September. BMFT also announced that Spiekermann was being withdrawn, and the conflict became an out and out battle between the ministry and the research centre. The ministry now plans to examine the scientific activities of the centre since 1973.

The latest chapter in the saga is the government's reply to the CDU/CSU's accusations in July. It reaffirms BMFT's desire to strengthen pure research rather than to concentrate on already well-explored areas. In addition, the government says it has long been convinced that the quality of the centre's research could be improved and that the routine work carried out runs counter to the aims of the centre. "Internal egoism", it says, has been responsible for the present situation; the attack against Neurath is merely an attempt to divert discussions from the real issues at stake.

Jasper Becker

\section{Productivity by numbers}

India, Eastern Europe and Israel stand out as being unusually scientific in the accompanying graph prepared by sociologist Dr Pedro Gonzalez-Blasco of the University Alcalá de Henares, Madrid.

The plot shows the number of scientists per hundred thousand population against gross national product (GNP) per capita in 1967. The box encloses Western European countries. The main trend is for the proportion of scientists to rise at about the third power of GNP per capita - so that scientists are added more rapidly per unit of additional GNP the higher the GNP. However, this may be read in two ways. Are the countries above the trend more effective at creating scientists? Or are their scientists less effective at creating wealth?

Dr Gonzalez-Blasco's plot forms part of the background to a seminar on the state of physics in certain less developed European countries to be held in Istanbul on 4-5 September under the auspices of the European Physical Society.

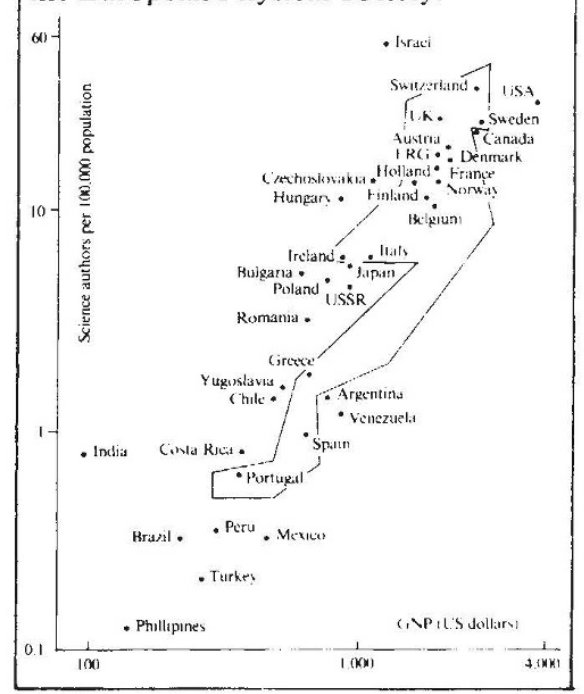

